EISSN: $2706-7947 \quad$ ISSN: $2077-4613$

DOI: 10.36632/mejas/2021.11.4.64

Journal homepage: www.curresweb.com

Pages: 839-848

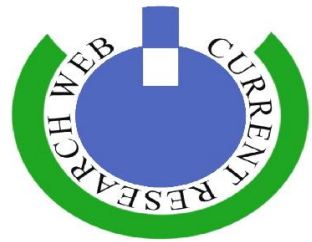

\title{
Fortification of Healthful Bread Gluten Free with Quinoa Seeds, Date Pits and Psyllium for Celiac Child
}

\author{
Mona S. Halaby ${ }^{1}$ and Mena M. Hanna ${ }^{2}$
}

${ }^{I}$ Nutrition and Food Science Dept., Faculty of Home Economics, Helwan Univ., Cairo, Egypt. ${ }^{2}$ Food Technologist, Design Engineer, IKEA of Sweden.

Received: 12 Sept. $2021 \quad$ Accepted: 14 Oct. $2021 \quad$ Published: 25 Oct. 2021

\begin{abstract}
In the present study, Quinoa Seeds Powder (QSP), Date Pits Powder (DPP) and Psyllium were studied as potential healthy ingredients for improving the nutritional quality of Gluten-Free Kaiser Bread (GFKB). Two samples of GFKB that were made from maize, rice and pysllium at two different ratios (3\% and $6 \%$ as control samples) without any supplementation have been conducted and evaluated. Another ten samples were fortified with QSP or DPP at different levels (15\% and 20\%), or mixed of QSP at $10 \%$ with DPP at $10 \%$ using 3\% and 6\% pysllium as alternative for gluten to improve nutritive value, taste, odor, texture, color and general appearance. The results showed that fortification of the GFKB with QSP or DPP at $15 \%$ and $20 \%$ or mixed from QSP and DPP at $10 \%+10 \%$ with $6 \%$ pysllium were the best treatment to improve its macro and micronutrients content and organoleptic evaluation which led to high nutritional value and an acceptable quality compared with those made without replacements.
\end{abstract}

Keywords: Celiac disease, Bread, Date pits, Quinoa seeds, Organoleptic evaluation.

\section{Introduction}

Celiac disease (CD) appears to be a widespread public health problem, it affects children of both sexes and women twice as much as it affects adults (Hamer 2005). When people with CD eat foods containing gluten, their immune system responds by damaging the finger-like villi of the small intestine, resulting in mal-absorption of nutrients due to an immunological reaction to gluten. Gluten-free diet is only lifelong treatment for celiac patients (Gordillo, 2016).

New recent epidemiological data show that celiac disease (CD) is often misdiagnosed, often as irritable bowel syndrome, chronic fatigue syndrome or fibromyalgia. Consequently, individuals may remain undiagnosed and untreated for many years. Gluten is one of the most abundant components of food (including grains); it is a composite of the proteins gliadin and glutenin. Celiac disease patients must consume food with gluten substitutes or gluten free grains (Halaby et al., 2014 and Ramandeep et al., 2018). The manufacture of quality gluten-free breads is one of the most challenging tasks in recent years. The scientific literatures assumed that gluten-free breads making should be based on a combination of starch sources along with gluten substitutes for nutritional reasons (Roman et al., 2019).

Regarding seeds and grains, present in $37 \%$ of the breads, the most commonly added are flax and sunflower, nigella sativa, sesame, chia, pumpkin, peanut or chickpea. These products provide nutrients such as protein, essential fatty acids, fibers, minerals, vitamins and antioxidants (Halaby et al., 2012; Morkos et al., 2013; Goyal et al., 2014 and Ullah et al., 2016).

Consumption of gluten free whole grains (rice and maize) not only provide an opportunity to delay the onset of lifestyle diseases, but they also help individuals on a gluten free diet obtain adequate amounts of vitamins and minerals that are often lacking in the diet, and are necessary for good health and wellbeing. Rice and maize flour is widely available and inexpensive ingredient with hypoallergenic properties confirmed by Hegazy et al. (2009) and Roman et al. (2019). 
Psyllium is a natural product, safest; stable at various $\mathrm{pH}$ levels and temperatures, being similar to gluten in food with proven nutritional benefits. It is already used to promote regulation of glucose control for diabetic patients and to reduce serum lipid levels in hyperlipidemics. Its benefits to protect from hemorrhoids; and helps reduce constipation problems, diarrhea, irritable bowel syndrome, inflammatory bowel disease, ulcerative colitis, and colon cancer. These properties allow its application in the food industry; pysllium can be a substitute for fat or act as an emulsifier or thickening agent. Moreover, psyllium has potential in new recipes for patients with celiac disease (Zandonadi et al., 2009 and Capriles, 2014).

Bread plays an important role in the human diet, it can be considered as the main source of energy, protein, carbohydrates, fiber, minerals and vitamins in diet. Furthermore, food fortification can be an economical, flexible, and socially acceptable to improve the nutrient intake of groups at risk, in order to ensure nutritional adequacy of the diet being an option by which people have access to milled or processed food (Granato \& Ellendersen 2009 and Halaby et al., 2014).

Quinoa is a nutritional and well-balanced food product with multiple functions associated with the reduction of chronic disease risk (Fuentes \& Bhargava 2011). Quinoa plant was called "the mother grain"; it is a grain with exceptional nutritional value; it has been cultivated for the last 5.000-7.000 years in the Indian region. It has a high biological value (73\%), similar to that of beef (74\%), and higher than those of white rice (56\%), wheat (49\%) and corn (36\%). It has protein content ranges from 12.9 to $16.5 \%$; as its protein levels are similar to those found in milk and higher than those present in cereals such as wheat, rice and maize. Quinoa also has been used by the National Aeronautics and Space Administration (NASA) due to its versatility in meeting the needs of humans during space missions (Tang et al., 2015b; Halaby et al., 2017 and Angeli et al., 2020).

According to the daily recommended amounts of amino acids indicated by the Food and Agriculture Organization (FAO) of the United Nations and by the World Health Organization (WHO), Quinoa fulfills the amino acid requirements for adults. For these reasons, Quinoa could represent a valuable source of nutrition, especially for infants and children. Quinoa grain has been authorized to be sown in Europe, North America, Asia and Africa. In Europe the project Quinoa a multipurpose crop for the European Community" was approved in 1993 (Gordillo, 2016). In 2013 was declared by the United Nations as the International Year of Quinoa as recognition of its significant potential. It has high concentrations of protein, unsaturated fatty acids, vitamins, minerals and other beneficial compounds, and is gluten-free by nature published by Halaby et al. (2017) and Ramandeep et al. (2018).

Date pits, also called pips, stones or seeds are by-products, which used in complementary and alternative medicine in an effort to prevent illness, reduces stress, or control disease showed by Sabah et al., (2010). Date pits, could be regarded as an excellent source of food ingredients with interesting technological functionality that could also be used in food as an important source of dietary fiber (Bouaziz et al., 2010 and Halaby et al., 2014). Chemical and nutritional constituents of date pits has been reported as containing 5-10\% moisture, $10-20 \%$ crude fiber, and $1-2 \%$ ash, with high amounts of carbohydrates $(75-80 \%)$, fat (10-12\%) and proteins (5-6\%) (Mobarak, 2009). Moreover, seeds contain high levels of phenolics (3102-4430 mg Gallic acid $1100 \mathrm{mg}$ ); it is considered as an important source to increase the antioxidant intake in the human diet by enriching food with phenolics mentioned by Amany et al. (2012) and Halaby et al. (2014).

Few researches have been published regarding incorporation of Quinoa seeds or Date pits powder or mixed from them with maize and rice flour to prepare free gluten bread with higher degree of acceptability. Therefore, the present study has been aimed to produce high quality and healthy nutritious Gluten-Free Kaiser Bread as sources of protein and various nutrients to produce natural products without any chemical preservatives or additives to be used for all ages of celiac patients.

\section{Material and Methods}

\subsection{Raw materials}

Maize (Zea mays L.), Rice (Oryza sativa L.), Dry Quinoa Seeds (Chenopodium quinoa W.) and Date Pits (Semi- dry) were obtained from Field Crops Research Institute of the Agricultural Research Centre, Cairo, Egypt. Psyllium, salt and active dry yeast were purchased from local market.

Preparation of Quinoa seeds: was washed, dried and crushed using electric blender. Date Palm pits were extracted from the date, washed in water several times to remove any adhering date flesh, and 
dried in an oven at $30^{\circ} \mathrm{C}$ for 48 hours. Pits were crushed using pestle and mortar followed by high speed laboratory blender and then sieved to obtain finely divided powder. Seeds powder was stored under refrigeration until processing and analyses.

\subsection{Methods}

\section{Chemical constituents of raw materials and Kaiser Bread}

Protein, total fat, ash, crude fiber and total carbohydrates were determined according to AOAC (2000). Minerals contents including Sodium (Na), Potassium (K), Calcium (Ca), Magnesium (Mg), Iron $(\mathrm{Fe})$ and $\mathrm{Zinc}(\mathrm{Zn})$ were determined in the raw materials using the atomic absorption spectrophotometer (3300 Perkin-Elme) as described by Chrom, (2006). Total fatty acids (saturated and unsaturated FA) were determined by "Hydrolytic Extraction Gas Chromatographic" according to the method described by ISO (1990 \& 2000).

\section{Preparation of Kaiser bread gluten-free in different blends}

The ingredients (raw material) used in Kaiser Bread formulas are given in Table (1). Kaiser breads were baked at $450-500^{\circ} \mathrm{C}$ for a relatively short time (2-3 minutes) in an electric oven. Kaiser bread was aerated at room temperature for at least $30 \mathrm{~min}$. After baking and cooling, the sensory evaluation was determined.

Table 1: Ingredients formula using Kaiser Bread on 100 gram flour.

\begin{tabular}{lccccccc}
\hline Formulas & Salt & Yeast & Psyllium & Maize & Rice & QS & DPP \\
\hline Control A & 1.0 & 2.0 & 3 & 47 & 47 & & - \\
Control B & 1.0 & 2.0 & 6 & 45.5 & 45.5 & & - \\
DPP + 3\% psy. & 1.0 & 2.0 & 3 & 39.5 & 39.5 & 15 & \\
DPP + 6\% psy & 1.0 & 2.0 & 6 & 35.5 & 35.5 & 20 & \\
QS + 3\% psy. & 1.0 & 2.0 & 3 & 39.5 & 39.5 & & 15 \\
QS + 6\% psy. & 1.0 & 2.0 & 6 & 35.5 & 35.5 & & 20 \\
DPP + QS +3\% psy. & 1.0 & 2.0 & 3 & 37 & 37 & 10 & 10 \\
DPP + QS +6\% psy. & 1.0 & 2.0 & 6 & 35.5 & 35.5 & 10 & 10 \\
\hline
\end{tabular}

\section{Sensory evaluation of Kaiser bread}

The scoring scheme was established according to A.A.C.C. (2002) by 30 trained panelists (staff members and students) from both, Nutrition and Food Science Department, Faculty of Home Economics, Helwan University; and stuffs in the Food Technology Research Institute, Giza - Egypt, for taste, odor, texture, crust color, crumb color, general appearance and overall acceptability.

\subsection{Statistical analysis}

The data obtained were analyzed by using SPSS statistical software (version 13 SPSS Inc., Chicago. USA). The results were expressed as mean \pm SD. Tested for significance using one-way analysis of variance "ANOVA" according to Armitage \& Berry (1987).

\section{Results and Discussion}

\subsection{Chemical composition of raw materials}

Yellow maize, white rice, psyllium, Quinoa seed powder and Date pits powder were investigated on dry weight basis. Results in Table (2) pointed out that Quinoa seed has the highest content of protein (16.3\%) followed by maize, rice and date pits $(8.49 \%, 7.22 \%$ and $6.68 \%)$. According to FAO/WHO recommendations, Quinoa protein can supply over $180 \%$ of the daily recommended intake of essential amino acids for adult nutrition (FAO 2011). Miranda et al., (2012b); Hejazi (2016) and USDA (2018) reported that Quinoa is equivalent to that of casein and dried whole milk, it is higher than that of rice, barley, corn, rye, sorghum and close to wheat.

The content of total fat in Date pits, Quinoa seed, maize and psyllium have the ratios $10.13 \%, 6.7 \%$, $4.14 \%$ and $3.66 \%$ respectively, while the rice flour has the lowest content of fat $(0.68 \% \mathrm{DW})$. Whereas, 
the highest total carbohydrate is in rice with ratio $91.24 \%$ followed by maize $85.01 \%$, Date pits and Quinoa seed 68.69\% and 68.34\%; while, the lowest ratio was in psyllium 7.34\%. Results in Table (2) point out that the psyllium is an excellent source of crude fiber and ash, the ratio reached to $60.33 \%$ and $27.34 \%$, respectively. Saturni et al. (2010) published that an adequate intake $(20-35 \mathrm{~g} / \mathrm{d})$ of fiber has to be recommended in celiac disease patients. As obtained and summarized in Tables 2 the fiber content in different raw material ranged from 0.48 to $60.33 \mathrm{~g} / 100 \mathrm{~g}$. These levels are higher with pysllium, DPP and QSP more than maize and rice. Therefore, their use in gluten-free diet can help to increase fiber intake in CD patients. On the same direction, the low content of ash and crude fiber are in rice and maize their ratios reached to $(0.38$ and $0.48 \%),(1.2$ and $1.16 \%)$, respectively. These results are in agreement to that obtained by Stevens \& Rashid (2008) and Halaby et al. (2012).

The data given in Table (2) illustrate that the raw materials contained various values of micro and macro-elements including iron $(\mathrm{Fe})$, zinc $(\mathrm{Zn})$, calcium $(\mathrm{Ca})$, magnesium $(\mathrm{Mg})$, sodium $(\mathrm{Na})$ and potassium (K). The results indicate that QSP contained the values of mineral with an average of 68, 42, $1042,2532,46$ and $885(\mathrm{mg} / 100 \mathrm{~g} \mathrm{DW})$, respectively. These results are in agreement with Vega-Gálvez et al. (2010); González et al. (2014); Hejazi (2016) and Halaby et al. (2017). They revealed that dietary minerals are essential chemical elements that play a role in regulating electrolyte balance, glucose homeostasis, the transmission of nerve impulses and enzyme cofactors in the body. Moreover, calcium, magnesium and potassium in quinoa are found in sufficient quantities and bio-available forms necessary for maintaining a balanced human diet. Results were also consistent with Ramandeep et al. (2018) and Li et al., (2021). They published that Quinoa is marvelous food due to its multi-functional characteristics and nutritional profile; it is ample in minerals as a good source of calcium, iron, magnesium, potassium and zinc. It is also pre-eminent for people with lactose intolerance and celiac disease.

Moreover, DPP has contained various levels of micro and macro-elements with an average of $43.10,16.82,184.80,1857.00,102.3$ and 1143.25 (mg/100g DW), respectively, compared with maize and rice flour which have low values of mineral contents. These results are in agreement with Rahman et al. (2007) and Nandhagopal et al. (2013) who showed that date seeds considered as a good source of calcium, magnesium, phosphorous, zinc, iron and potassium. Bouhlali et al. (2017) mentioned that the consumption of $100 \mathrm{~g}$ of date seeds can provide over $14 \%$ of the recommended daily allowance of magnesium, iron, copper, and manganese and more than $7 \%$ of zinc, however it covers less than $4 \%$ of calcium. This important content of microelement can encourage food industries to use the flour of date pits to fortify their products. At the same time, Psyllium has the highest content of $\mathrm{K}, \mathrm{Ca}, \mathrm{Na}, \mathrm{Mg}$ and $\mathrm{Fe}(811.37,334.54,27.34,54.62,51,82 \mathrm{and} 20.91 \mathrm{mg} / 100 \mathrm{~g})$ respectively, compared with maize and rice flour; while, Psyllium has the lowest content of Fe, $\mathrm{Zn}, \mathrm{Mg}$ and $\mathrm{K}$ compared with Quinoa seed and date pits (Halaby et al., 2012).

Table 2: The chemical analysis of raw materials on dry weight basis

\begin{tabular}{lccccc}
\hline Chemical analysis & Maize & Rice & Psyllium & QSP & DPP \\
\hline Protein (g/100gm) & 8.49 & 7.22 & 1.33 & 16.30 & 6.68 \\
Total fat & 4.14 & 0.68 & 3.66 & 6.70 & 10.13 \\
Ash & 1.16 & 0.38 & 27.34 & 3.50 & 1.09 \\
Crude fiber & 1.20 & 0.48 & 60.33 & 5.16 & 12.41 \\
Total carbohydrates & 85.01 & 91.24 & 7.34 & 68.34 & 69.69 \\
\hline & \multicolumn{5}{c}{ Minerals (mg/100g) } \\
Iron (Fe) & 4.60 & 4.51 & 20.91 & 68 & 43.10 \\
Zinc (Zn) & 2.72 & 2.30 & 2.73 & 42 & 16.82 \\
Calcium (Ca) & 20.85 & 32.39 & 334.54 & 1042 & 184.80 \\
Magnesium (Mg) & 3.59 & 1.20 & 51.82 & 2532 & 1857.0 \\
Sodium (Na) & 15.97 & 12.30 & 54.62 & 46 & 102.3 \\
Potassium (K) & 192.35 & 185.64 & 811.37 & 885 & 1143.25 \\
\hline
\end{tabular}

\subsection{Fatty acid contents of Quinoa seed and date pits powder on dry weight basis}

The data presented in Table (3) showed that the types and concentrations of fatty acid extracted from the QSP and DPP using gas chromatography, eight saturated fatty acids and five unsaturated 
fatty acids were recognized in date seeds powder. On the other side, the results revealed that five saturated fatty acids were recognized in Quinoa seeds powder, besides four unsaturated fatty acids were identified in the same variety.

The results given in Table (3) revealed that the Linolenic acid was the primary unsaturated fatty acids in date seeds with concentration $15.068 \%$, it was followed by Linoleic acid (14.886\%), Oleic acid (14.035\%), Heptadecenoic acid (12.152\%) and Hexadecenoic acid (10.619\%), respectively. The most abundant saturated fatty acids in date pits are Ligoceric acid, Docosanoic acid, Arachidic acid, Stearic acid, Margarinic acid Palmitic acid, Myrisitic acid and Lauric acid with values $24.686 ; 24.836 ; 20.281$; $20.310 ; 16.864 ; 16.868 ; 13.556 ; 13.578 ; 11.682 ; 11.693 ; 10.181 ; 10.194 ; 7.879 ; 7.883$ and $6.206 ; 6.208$ $\mathrm{mg} / 100 \mathrm{~g}$, respectively. The obtained data confirmed by Halaby et al. (2014) and Bouhlali et al., (2017) revealed that the most abundant fatty acids of date seed were oleic, lauric, myristic, palmitic and linoleic acids.

The results given in the same table showed that the most abundant saturated fatty acid in QSP was Palmitic acid (11.40\%). Results detected other quantities of fatty acids including Eicosenic acid $(01.14 \%)$, Stearic acid (00.79\%), Arachidic $(00.29 \%)$ and Behenic acid $(00.24 \%)$ which are among the minor FA found in QSP. The results revealed also that the total saturated fatty acid, monounsaturated and polyunsaturated fatty acids in Quinoa seeds powder were 13.86; 26.17 and 59.97 (g/ 100g), and the most abundant poly and mono-unsaturated fatty acids in Quinoa seeds powder were Linoleic and Linolenic acids $(52.84 \%$ \& $07.13 \%)$ and Oleic acids $(25.60 \%)$.

Quinoa provides good-quality lipids rich in unsaturated fatty acids (Hejazi 2016). The obtained data are consistent with those of Vega-Gálvez et al. (2010); Mora et al. (2013); Tang et al. (2015) and Gordillo et al. (2016) who showed that the total lipid content of quinoa is $14.5 \%$, with approximately $70 \%-89.4 \%$ being unsaturated $(38.9 \%-57 \%$ of linoleic acid, $24.0 \%-27.7 \%$ of oleic acid and $4 \%$ of $\alpha-$ linolenic acid). Our results indicated that Quinoa seed showed higher unsaturated fatty acids than that of date pits.

Table 3: Fatty acids content of Quinoa seeds powder and date pits powder ( $\mathrm{mg} / 100 \mathrm{~g}$ dry weight basis)

\begin{tabular}{|c|c|c|}
\hline \multirow{2}{*}{ Fatty acids } & \multicolumn{2}{|c|}{ Material } \\
\hline & QSP & DPP \\
\hline \multicolumn{3}{|l|}{ Unsaturated FA } \\
\hline Hexadecenoic acid C 16:1 $\omega 7$ & - & 10.619 \\
\hline Heptadecenoic acid C 17:1 & - & 12.152 \\
\hline Oleic acid C18:1 09 & 25.60 & 14.035 \\
\hline Linoleic acid C 18:2 $\omega-6$ & 52.84 & 14.886 \\
\hline Linolenic acid C 18:3 $\omega 3$ & 07.13 & 15.068 \\
\hline Erucic acid & 00.57 & - \\
\hline \multicolumn{3}{|l|}{ Saturated FA } \\
\hline Lauric acid C 12:0 & - & 6.206 \\
\hline Myrisitic acid C 14:0 & - & 7.879 \\
\hline Palmitic acid C16:0 & 11.40 & 10.181 \\
\hline Margarinic acid C 17:0 & - & 11.682 \\
\hline Stearic acid C 18:0 & 00.79 & 13.556 \\
\hline Arachidic acid C 20:0 & 00.29 & 16.864 \\
\hline Docosanoic acid $\mathrm{C}_{22} \mathrm{H}_{44} \mathrm{O}_{22}$ & - & 20.281 \\
\hline Ligoceric acid $\mathrm{C}_{24} \mathrm{H}_{48} \mathrm{O}_{24}$ & - & 24.686 \\
\hline Eicosenic acid & 01.14 & - \\
\hline Behenic acid & 00.24 & - \\
\hline
\end{tabular}

QSP: Quinoa seeds powder

DPP: Date pits powder 


\subsection{Chemical constituents of gluten-free Kaiser Bread (GFKB) fortified with QSP; DPP and Psyllium (g/100g DW)}

The demand for many nutrients is increased with celiac patients, in recent years, there has been increasing interest in identifying food and by-products that can serve as functional foods and nutraceuticals to enhance the well-being of individuals and reduce the risk of various diseases and disorders, besides mal-absorption associated with disease or inadequate intakes of supplementation nutrients. In fact, gluten free bread (without supplements) was insufficient in all nutrients and energy.

Chemical composition of Kaiser bread made from maize and rice flour using psyllium at $3 \%$ and $6 \%$ (control A \& B) as alternative gluten to give the dough thickeners and gelling agents, compared with the other formulas of bread after addition of QSP or DPP which replaced at various levels $15 \%$ and $20 \%$; or after addition mixed of $10 \%$ QSP and $10 \%$ DPP. It could be recorded that protein, total fat, ash and crude fiber contents are 8.98, 2.84, 3.51 and $8.23 \%$ with $3 \%$ psyllium and the contents are 9.10, $3.15,4.01$ and $9.05 \%$ respectively with $6 \%$ psyllium (as control samples). According to Granato \& Ellendersen (2009) and Rai et al. (2018) published that the psyllium and other flours including rice and maize, have very important recipes potential for patients with celiac disease.

Regarding the chemical composition of GFKB samples, it could be noticed (Tables 4) that the GFKB which was fortified separately in different ways ( $15 \%$ or $20 \%$ QSP) or ( $15 \%$ or $20 \%$ DPP) and after mixed (10\% QSP and $10 \%$ DPP) with $3 \%$ or $6 \%$ pysllium improved the macro and micronutrients more than that of the corresponding control sample containing $3 \%$ or $6 \%$ pysllium only without any fortification.

Table 4: Chemical composition of gluten-free Kaiser Bread fortified with different levels of QSP; DPP and Psyllium at 3\% and $6 \%$ (on dry weight basis).

\begin{tabular}{|c|c|c|c|c|c|c|c|c|c|c|c|c|}
\hline \multirow{4}{*}{$\begin{array}{l}\text { Chemical } \\
\text { analysis }\end{array}$} & \multicolumn{12}{|c|}{ Blends of QSP; DPP and Psyllium at $3 \%$ and $6 \%$} \\
\hline & \multirow{2}{*}{\multicolumn{2}{|c|}{$\begin{array}{c}\text { Control } \\
\text { A \& B }\end{array}$}} & \multicolumn{4}{|c|}{ QSP } & \multicolumn{4}{|c|}{ DPP } & \multirow{2}{*}{\multicolumn{2}{|c|}{$\begin{array}{l}\text { QSP + DPP } \\
10 \%+10 \%\end{array}$}} \\
\hline & & & \multicolumn{2}{|c|}{$15 \%$} & \multicolumn{2}{|c|}{$20 \%$} & \multicolumn{2}{|c|}{$15 \%$} & \multicolumn{2}{|c|}{$20 \%$} & & \\
\hline & $3 \%$ & $6 \%$ & $3 \%$ & $6 \%$ & $3 \%$ & $6 \%$ & $3 \%$ & $6 \%$ & $3 \%$ & $6 \%$ & $3 \%$ & $6 \%$ \\
\hline Protein & 8.98 & 9.10 & 14.81 & 14.97 & 15.28 & 15.49 & 11.70 & 11.95 & 12.01 & 12.45 & 12.37 & 13.57 \\
\hline Total fat & 2.84 & 3.15 & 8.09 & 9.29 & 8.90 & 9.88 & 15.48 & 15.99 & 15.91 & 16.04 & 10.98 & 12.05 \\
\hline Ash & 3.51 & 4.01 & 4.39 & 4.90 & 4.80 & 4.93 & 5.23 & 5.37 & 5.74 & 5.92 & 4.29 & 5.07 \\
\hline Crude fiber & 8.23 & 9.05 & 9.39 & 9.70 & 9.62 & 9.87 & 9.45 & 9.98 & 10.62 & 10.87 & 9.48 & 10.25 \\
\hline $\begin{array}{c}\text { Total } \\
\text { Carbohydrate }\end{array}$ & 76.44 & 74.69 & 63.32 & 61.14 & 61.40 & 59.83 & 58.14 & 56.71 & 55.72 & 54.72 & 62.91 & 59.06 \\
\hline \multicolumn{13}{|c|}{ Minerals (mg / 100g) } \\
\hline $\mathbf{F e}$ & 6.30 & 6.86 & 6.86 & 7.39 & 7.47 & 7.99 & 5.08 & 5.61 & 5.19 & 5.78 & 5.24 & 6.05 \\
\hline Zn & 2.61 & 3.12 & 2.81 & 3.45 & 2.90 & 3.93 & 2.84 & 2.92 & 3.01 & 3.11 & 3.17 & 3.25 \\
\hline $\mathrm{Ca}$ & 156.8 & 179.2 & 313.1 & 372.9 & 461.5 & 473.3 & 207.9 & 219.7 & 218.1 & 230.7 & $7 \quad 261.1$ & 309.3 \\
\hline Mg & 29.54 & 34.23 & 183.5 & 192.3 & 196.5 & 215.2 & 109.3 & 118.8 & 110.7 & 119.7 & $7 \quad 124.7$ & 137.2 \\
\hline $\mathbf{N a}$ & 30.29 & 31.34 & 32.24 & 38.99 & 33.77 & 39.74 & 38.91 & 39.45 & 41.31 & 43.29 & $\quad 32.97$ & 40.15 \\
\hline $\mathbf{K}$ & 313.7 & 326.9 & 480.6 & 495.5 & 488.2 & 503.1 & 895.9 & 920.8 & 903.4 & 945.2 & 674.1 & 703.3 \\
\hline
\end{tabular}

It could be noticed also that, total nutrients (protein, total fat, ash, crude fiber) and minerals (iron, zinc, calcium, magnesium, sodium and potassium) were gradually increased when using $20 \%$ QSP or $20 \%$ DPP. Also, mixture of QSP and DPP together with 6\% pysllium, shows significant increase in various nutrients compared with the same samples of GFKB fortified with QSP or DPP or mixed powder at $10 \%$ with $3 \%$ pysllium. While, carbohydrate contents were slightly decreased in GFKB samples fortified with different ratios separately or mixed from QSP or DPP at 3\% or at $6 \%$ psyllium compared with the unfortified samples.

In general most GFKB samples had superior nutritional value compared with control sample. It may be notice that the GFKB made with psyllium with QSP or DPP or mixed from QSP \& DPP help to improve nutrients content and prevent nutritional deficiencies of celiac disease. The present results are in agreement with previous studies (Amany et al., 2012; Afifi et al., 2017 and Li et al., 2021). On the other hand, the control Kaiser bread (psyllium 3\% \& 6\%) had the highest contents of the 
carbohydrate (76.44 \& $74.69 \mathrm{~g} / 100 \mathrm{~g} \mathrm{DW})$, confirmed by Zandonadi et al. (2009) and Halaby et al. (2012) who reported that Psyllium was chosen because it is stable at various $\mathrm{pH}$ levels and temperatures, being similar to gluten in food; these properties allow its application in the food industry, pysllium can be a substitute for fat or act as an emulsifier or thickening agent.

The results indicate that Quinoa seeds and date pits are an excellent sources of functional food ingredient in nutraceuticals and may be pharmaceuticals, as well as in the production of nutritional gluten-free bread. Gordillo (2016) showed that Quinoa complies with the Codex Alimentarius nomenclature of gluten-free products (gluten content $<20 \mathrm{mg} / \mathrm{kg}$ ). Date pits, which are cheap in price with high energy content, is considered as an ideal food, provides a wide range of essential nutrients and potential health benefits confirmed by Hadrami \& Al-Khayri (2012); Nandhagopal et al. (2013); Halaby et al. (2017) and Roman et al. (2019).

\subsection{Organoleptic evaluation of gluten-free Kaiser Bread fortified with different levels of QSP, DPP and Psyllium at $3 \%$ and $6 \%$ :}

The characteristics of replacing maize and rice flour with Quinoa seeds, date pits powder and psyllium under different levels on sensory evaluation of Kaiser are shown in Table (5). Results indicate differences between various blends as compared to the control two samples with $3 \%$ or $6 \%$ psyllium. Two control samples without adding any ingredients have the lowest score in all organoleptic properties.

Most of panelists preferred the taste, odor, texture, crust color, crumb color, general appearance and overall acceptability of Kaiser breads made from $10 \%$ QSP and $10 \%$ DPP with 3\% and $6 \%$ psyllium replaced with maize and rice flour.

These results proved that processing bread with QSP and/or DPP with psyllium could be regarded as an excellent source of food ingredients with interesting technological functionality that could also be used in food as an important source of dietary fiber and different nutrients. These results have been confirmed by Schoenlechner et al. (2010); Najafi (2011) and Halaby et al. (2017). They showed that bread containing $10 \%$ date seed fiber had higher dietary fiber content and similar sensory properties to the wheat bran control. In fact, developing and improving bread and other food bakery products with various natural additives such as (QSP or DPP) are important to help patients with celiac disease.

Table 5: Organoleptic evaluation of gluten-free Kaiser Bread fortified with different levels of QSP; DPP and Psyllium at 3\% and $6 \%$.

\begin{tabular}{|c|c|c|c|c|c|c|c|}
\hline Types of additions & $\begin{array}{c}\text { Taste } \\
\mathbf{2 0}\end{array}$ & $\begin{array}{c}\text { Odor } \\
\mathbf{2 0}\end{array}$ & $\begin{array}{c}\text { Volume } \\
15\end{array}$ & $\begin{array}{c}\text { Crust color } \\
15\end{array}$ & $\begin{array}{c}\text { Crumb } \\
\text { color } \\
15 \\
\end{array}$ & $\begin{array}{c}\text { General } \\
\text { appearance } \\
15 \\
\end{array}$ & $\begin{array}{c}\text { Overall } \\
\text { acceptability } \\
100 \\
\end{array}$ \\
\hline Control A 3\% & $17.10^{\mathrm{c}} \pm 0.76$ & $17.00^{\mathrm{d}} \pm 0.79$ & $12.35^{\mathrm{d}} \pm 0.93$ & $12.31^{\mathrm{c}} \pm 0.64$ & $12.18^{\mathrm{c}} \pm 0.93$ & $11.20^{\mathrm{d}} \pm 0.63$ & 82.14 \\
\hline Control B 6\% & $17.15^{\mathrm{c}} \pm 0.21$ & $17.62^{c} \pm 0.35$ & $13.85^{\mathrm{c}} \pm 0.35$ & $12.89^{c} \pm 0.34$ & $12.52^{\mathrm{c}} \pm 0.87$ & $11.37^{\mathrm{d}} \pm 0.43$ & 85.40 \\
\hline QSP 15\% + 3\% Psy & $17.00^{\mathrm{cd}} \pm 1.08$ & $17.83^{c} \pm 0.89$ & $12.95^{\mathrm{d}} \pm 0.97$ & $12.69^{c} \pm 0.78$ & $13.17^{\mathrm{b}} \pm 0.23$ & $13.27^{\mathrm{c}} \pm 0.74$ & 86.91 \\
\hline QSP 15\% + 6\% Psy & $18.13^{\mathrm{b}} \pm 0.06$ & $17.82^{c} \pm 0.33$ & $14.54^{\mathrm{ab}} \pm 0.37$ & $11.67^{\mathrm{d}} \pm 0.78$ & $11.23^{\mathrm{d}} \pm 0.07$ & $13.83^{\mathrm{b}} \pm 0.45$ & 87.21 \\
\hline QSP 20\% + 3\% Psy & $18.53^{\mathrm{b}} \pm 0.55$ & $18.00^{\mathrm{b}} \pm 0.01$ & $13.97^{\mathrm{c}} \pm 0.01$ & $12.14^{\mathrm{c}} \pm 0.78$ & $11.95^{\mathrm{d}} \pm 0.31$ & $13.71^{b c_{ \pm}} 0.19$ & 88.30 \\
\hline QSP $20 \%+6 \%$ Psy & $17.60^{c} \pm 0.06$ & $18.05^{\mathrm{b}} \pm 0.98$ & $13.38^{\mathrm{c}} \pm 0.95$ & $12.96^{\mathrm{bc}} \pm 0.99$ & $13.82^{\mathrm{b}} \pm 0.22$ & $13.75^{\mathrm{b}} \pm 0.77$ & 89.56 \\
\hline DPP $15 \%+3 \%$ Psy & $18.95^{\mathrm{ab}} \pm 0.06$ & $18.41^{\mathrm{b}} \pm 0.39$ & $14.23^{\mathrm{b}} \pm 0.92$ & $12.85^{\mathrm{bc}} \pm 0.78$ & $12.12^{\mathrm{cd}} \pm 0.07$ & $13.98^{\mathrm{b}} \pm 0.66$ & 90.54 \\
\hline DPP $15 \%+6 \%$ Psy & $19.15^{\mathrm{a}} \pm 0.71$ & $18.87^{\mathrm{ab}} \pm 0.44$ & $14.41^{\mathrm{b}} \pm 0.06$ & $13.12^{b} \pm 0.85$ & $12.45^{\mathrm{c}} \pm 0.62$ & $14.35^{\mathrm{ab}} \pm 0.16$ & 92.35 \\
\hline DPP $20 \%+3 \%$ Psy & $18.84^{\mathrm{ab}} \pm 0.63$ & $18.88^{\mathrm{ab}} \pm 0.69$ & $14.89^{\mathrm{a}} \pm 0.321$ & $13.82^{\mathrm{b}} \pm 0.11$ & $14.32^{\mathrm{ab}_{ \pm}} \pm 0.37$ & $14.20^{\mathrm{ab}_{ \pm}} \pm 0.69$ & 94.95 \\
\hline DPP $20 \%+6 \%$ Psy & $19.00^{\mathrm{a}} \pm 0.81$ & $18.87^{\mathrm{ab}} \pm 0.97$ & $14.17^{\mathrm{a}} \pm 0.28$ & $14.01^{\mathrm{a}} \pm 0.75$ & $14.19^{\mathrm{a}} \pm 0.07$ & $14.78^{\mathrm{a}} \pm 0.69$ & 95.02 \\
\hline $\begin{array}{l}\text { QSP + DPP } 10 \%+ \\
10 \%+3 \% \text { Psy }\end{array}$ & $19.23^{\mathrm{a}} \pm 0.88$ & $19.00^{\mathrm{a}} \pm 0.99$ & $14.86^{\mathrm{a}} \pm 0.47$ & $14.09^{\mathrm{a}} \pm 0.74$ & $14.31^{\mathrm{ab}_{ \pm}} \pm 0.15$ & $14.79^{a} \pm 0.42$ & 96.28 \\
\hline $\begin{array}{l}\text { QSP + DPP } 10 \%+ \\
10 \%+6 \% \text { Psy }\end{array}$ & $19.30^{\mathrm{a}} \pm 0.19$ & $19.60^{\mathrm{a}} \pm 0.63$ & $12.88^{\mathrm{d}_{ \pm}} \pm 0.23$ & $14.84^{\mathrm{a}} \pm 0.56$ & $14.89^{\mathrm{a}} \pm 0.88$ & $14.96^{\mathrm{a}} \pm 0.39$ & 97.74 \\
\hline
\end{tabular}

The average of total score was converted to a descriptive category as follows:

V. good: 90 - 100; Good: 80 - 89; Acceptable: 70 - 79 and Poor: less than 70. 


\section{Recommendation}

Nowadays there is an increasing interest toward the potential health benefits of medicinal plants. Food industries should be encouraged to use Quinoa seeds and date pits powder for bakery products fortification to be included in wide scale in the meal.

Recent attention to natural plants through nutrition education programs should be designed to inform the public about the effect of Quinoa seeds and/or date pits powder with psyllium incorporation in bread and with different baked products to decrease the risk of celiac disease.

\section{References}

A.A.C.C., 2002. An Approved Methods of American Association of Cereal Chemists. In St. Paul. Minnesota. USA.

Afifi, H., I. Hashim and S. Altubji, 2017. Optimizing extraction conditions of crude fiber, phenolic compounds, flavonoids and antioxidant activity of date seed powder. J. Food Sci. Technol., 54(13):4149-4161.

Amany, M., M. Shaker, and A. Abeer, 2012. Antioxidant activities of date pits in a model meat system. International Food Research Journal, 19 (1): 223-227.

Angeli, V., P. Silva, D. Massuela, M. Khan, A. Hamar, F. Khajehei, S. Graeff-Hönninger, and C. Piatti, 2020. Quinoa (Chenopodium quinoa Willd.). An Overview of the Potentials of the "Golden Grain" and Socio-Economic and Environmental Aspects of Its Cultivation and Marketization. Foods 9, 216.

AOAC., 2000. Association of Official Analytical Chemist Official Methods of Analysis $17^{\text {th }}$ ed., Washington, USA.

Armitage, P. and G. Berry, 1987. Statistical method in medical research. Blackwell, Oxford, UK, 93 213.

Bouaziz, M., W. Amara, H. Attia, C. Blecker, and S. Besbes, 2010. Effect of the addition of defatted date seeds on wheat dough performance and bread quality. Journal of Texture Studies, 41: 511-531.

Bouhlali, E., C. Alem, J. Ennassir, M. Benlyas, A. Mbark, and Y. Zegzouti, 2017. Phytochemical compositions and antioxidant capacity of three date (Phoenix dactylifera L.) seeds varieties grown in the South East Morocco. Journal of the Saudi Society of Agricultural Sciences, 16: 350-357.

Capriles, V.D., and J.A. Areas, 2014. Novel approaches in gluten-free breadmaking: Interface between food science, nutrition, and health. Comprehensive Reviews in Food Science and Food Safety, 13: 871-890.

FAO, 2011. Quinoa: an ancient crop to contribute to world food security. Available from: http://www.fao.org/docrep/017/aq287e/aq287e.pdf. Accessed 2014 August 8.

Fuentes, F. and A. Bhargava, 2011. Morphological analysis of quinoa germplasm grown under lowland desert conditions. Journal of Agronomy and Crop Science, 197: 124-134.

González, M., G. Wells Moncada, S. Fischer, and O. Escuredo, 2014. Chemical characteristics and mineral composition of quinoa by nearinfrared spectroscopy. J. Sci. Food Agric., 94: 876-881.

Gordillo, S.B., D. Díaz-Rizzolo, E. Roura, T. Massanés, and R. Gomis, 2016. Quinoa (Chenopodium quinoa Willd), from Nutritional Value to Potential Health Benefits: An Integrative Review. J Nutr. Food Sci. 6 (3): 2-10.

Goyal, A., V. Sharma, N. Upadhyay, S. Gill, and M. Sihag, 2014. Flax and flaxseed oil: An ancient medicine \& modern functional food. Journal Food of Science and Technology, 51: 1633-1653.

Granato, D. and L. Ellendersen, 2009. Almond and peanut flours suppelmented with iron as potential ingredients to develop gluten-free cookies. Ciênc. Tecnol. Aliment., Campinas, 29(2): 395-400.

Hadrami, A. and J. Al-Khayri, 2012. Socioeconomic and traditional importance of date palm. Emir. J. Food Agric., 24 (5): 371-385.

Halaby, M.S., R.N. Sandak, H.A. Jambi, and S.A. Kokandi, 2012. Fortification of pan bread gluten free with Nigella Sativa and Sesame for celiac patients. J. Biol. Chem. Environ., Sci., 7 (4), 27-40.

Halaby, M.S., M.K. Abdel-Rahman, and R.A. Hassan, 2017. Effect of Quinoa seeds on hypercholesterolemia in male rats. Egyptian J. of Nutrition and Health. Published by Society of Feeding mind, Combating malnutrition.12 (1), PP: 67-86. ISSN 1687-7950. 
Halaby, M.S., M.K. Abdel-Rahman, and R.A. Hassan, 2017. Protective Influence of Quinoa on Hypercholesterolemia in Male Rats. Current Science International, 6(1): 259-270.

Halaby, M.S., M.H. Farag, and A.H. Gerges, 2014. Potential Effect of Date Pits Fortified Bread on Diabetic Rats. International Journal of Nutrition and Food Sciences, 3(2): 49-59.

Hamer, R., 2005. Coeliac disease: Background and biochemical aspects. Biotechnol Adv., 23: 401- 408.

Hegazy, A., M. Ammar, and M. Ibrahium, 2009. Production of Egyptian Gluten-Free Bread. World Journal of Dairy and Food Sciences, 4 (2): 123-128.

Hejazi, M., 2016. Preparation of different formulae from quinoa and different sources dietary fiber to treat obesity in rats. Nature and Science; 14 (2): 55-65.

International Organization for Standardization, ISO. 5508, 1990. Animal and vegetable fats and oilsAnalysis by gas chromatography of methyl esters of fatty acids.

International Organization for Standardization, ISO. 5509, 2000. Animal and vegetable fats and oilsPreparation of methyl esters of fatty acids.

Journal of chromatography B., 2006. 830: $41-46$.

Li, L., G. Lietz and C. Seal, 2021. Phenolic, apparent antioxidant and nutritional composition of Quinoa (Chenopodium Quinoa Willd.) seeds. International Journal of Food Science and Technology, 56: 3245-3254

Miranda, M., A. Vega-Galvez, I. Quispe-Fuentes, M. Rodriguez, H. Maureira, and E. Martinez, 2012b. Nutritional aspects of six quinoa (Chenopodium quinoa Willd.) ecotypes from three geographical areas of Chile. Chilean J. Agric. Res., 72(2):175-81.

Mobarak, S.A., 2009. Antioxidant properties of date palm (Phoenix dactylifera L.) cultivars. Ph.D. Colorado State University.

Mora, A., M. Lares, R. Gutiérrez, R. Diaz, M. Hernández, and J. Trujillo, 2013. Quinoa pasta influences some biochemical markers in Consumers. Foods 2013 ISSN 2304-8158.

Morkos, M., M. Halaby, R. Sandak, and M. Hanna, 2013. Microbiological Analysis of Fortified Cakes with Peanut and Chickpea to Celiac Patients. Journal of Applied Sciences Research, 9 (4): 3263 3270 .

Najafi, M., 2011. Date Seeds: A Novel and Inexpensive Source of Dietary Fiber. International Conference on Food Engineering and Biotechnology, 323- 326.

Nandhagopal, K., M. Kanniyakumari, J. Anbu, and V. Velpandian, 2013. Antidiabetic activity of karchure chooranam on alloxan induced diabetic rats. Int. J. Pharm. Bio. Sci. Jan., 4 (1): 434 - 439.

Rahman, M., S. Kassapis, N. Al-Kharusi, I. Al-Marhubi, and A. Khan, 2007. Composition characterization and thermal transition of date pits powder. J. Food Engineering, 80 (1): 1-10.

Rai, S., A. Kaur, and C. Chopra, 2018. Gluten-Free Products for Celiac Susceptible People. Frontiers in Nutrition, 5: 1-23.

Ramandeep, R., P. Ahluwalia, P. Sachdev, and A. Kaur, 2018. Development of gluten-free cereal bar for gluten intolerant population by using quinoa as major ingredient. J Food Sci. Technol., 55(9):3584-3591.

Roman, L., M. Belorio, and M. Gomez, 2019. Gluten-Free Breads: The Gap between Research and Commercial Reality. Comprehensive Reviews in Food Science and Food Safety, 18: 690 - 702.

Sabah, A., A. Jassim, and M. Naji, 2010. In vitro evaluation of the antiviral activity of an extract of date palm (Phoenix dactylifera L.) pits on a pseudomonas phage. Evid Based Complement Alternat Med., 7(1): 57-62.

Saturni, L., G. Ferretti, and T. Bacchetti, 2010. The Gluten-Free Diet: Safety and Nutritional Quality Nutrients, 2: 16-34.

Schoenlechner, R., J. Drausinger, V. Ottenschlaeger, K. Jurackova, and E. Berghofer, 2010. Functional properties of gluten-free pasta produced from amaranth, quinoa and buckwheat. Plant Foods for Human Nutrition, 65: 339-349.

Stevens, L. and M. Rashid, 2008. Gluten-free and regular foods: a cost comparison. Can. J. Diet. Pract. Res., 69, 147-50.

Tang, Y., X. Li, P. Chen, B. Zhang, and M. Hernandez, 2015b. Characterisation of fatty acid, carotenoid, tocopherol/tocotrienol compositions and antioxidant activities in seeds of three Chenopodium quinoa Willd. genotypes. Food chemistry, 174: 502-508. 
Tang, Y., X. Li, B. Zhang, P. Chen, and R. Liu, 2015. Characterisation of phenolics, betanins and antioxidant activities in seeds of three Chenopodium quinoa Willd. genotypes. Food Chem., 166: 380388.

U.S. Department of Agriculture, USDA, Agricultural Research Servize, 2018. USDA branded food products database. Nutrient data laboratory home page. Retrieved from http://ndb.nal.usda.gov

Ullah, R., M. Nadeem, A. Khalique, M. Imran, S. Mehmood, A. Javid, and J. Hussain, 2016. Nutritional and therapeutic perspectives of Chia (Salvia hispanica L.): A review. Journal of Food Science and Technology, 53: 1750-1758.

Vega-Galvez, A., M. Miranda, J. Vergara, E. Uribe, and L. Puente, 2010. Nutrition facts and functional potential of quinoa (Chenopodium quinoa Willd.), an ancient Andean grain: a review. J. Sci. Food Agric., 90: 2541-2547.

Zandonadi, R., R. Botelho, and W. Araújo, 2009. Psyllium as a Substitute for Gluten in Bread. J. Am. Diet Assoc., 109: $1781-1784$. 